Revista Brasileira de Farmacognosia Brazilian Journal of Pharmacognosy 22(4): 894-905, Jul./Aug. 2012

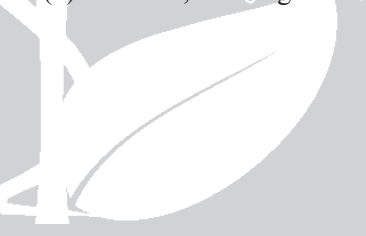

Review

Received 1 Nov 2011

Accepted 23 Dec 2011

Available online 5 Jun 2012

Keywords:

seaweeds

marine natural products

bioprospection

ISSN 0102-695X

http://dx.doi.org/10.1590/S0102-

695X2012005000077

\section{Bioprospecting for bioactives from seaweeds: potential, obstacles and alternatives}

\author{
Renato C. Pereira, ${ }^{* 1}$ Leticia V. Costa-Lotufo ${ }^{2}$ \\ ${ }^{1}$ Universidade Federal Fluminense, Instituto de Biologia, Departamento de Biologia \\ Marinha, Brazil, \\ ${ }^{2}$ Universidade Federal do Ceará, Instituto de Ciências do Mar, Brazil.
}

\begin{abstract}
Seaweeds are potential sources of high biotechnological interest due to production of a great diversity of compounds exhibiting a broad spectrum of biological activities. On the other hand, there is an urgent need for management options for a sustainable approach to the use of marine organisms as a source of bioactive compounds. This review discusses the bioprospection for bioactive seaweed compounds as pharmaceuticals and antifouling agents, encompassing their potential and possible obstacles and alternatives. In spite of their potential, research on pharmaceuticals and antifouling agents from seaweeds includes mainly the search for molecules that exhibit these biological activities, but lacks of consideration of fundamental and limiting aspects such as the development of alternatives to sustainable supply. However, for the complete development of pharmaceuticals and antifouling compounds in Brazil, marine bioprospection should be more comprehensive, associating the search for molecules with an analysis of their supply. In this way, it is possible to promote sustainable development and conservation of biodiversity, as well as to assert the economic development of Brazil.
\end{abstract}

\section{Introduction}

Although the marine environment covers about $70 \%$ of the planet's surface and holds high biodiversity (Tittensor et al., 2010), very few species have been explored or used for biotechnological purposes. However, the "marine world" is endowed with diverse life forms that constitute a rich resource for the development of a wide array of applications (Demunshi \& Chugh, 2010). For example, the marine environment is the source of structurally unique secondary metabolites produced by different organisms such as sponges, tunicates, bryozoans, soft corals, mollusks, microorganisms and seaweeds (Blunt et al., 2011). These metabolites have attracted the attention of chemists and biologists for the past five decades, because several of these chemicals exhibit pronounced pharmacological (e.g., Mayer et al., 2010) and antifouling activities (e.g., Hellio \& Yebra, 2009). As such, they are interesting candidates for new drugs and antifouling paint development, respectively.

Secondary metabolites from terrestrial plants have been or are the basis of much of human disease therapy and are often the major component of modern pharmaceuticals. About $60 \%$ of the world's population relies almost entirely on plants for medication (Farnsworth, 1994), reflecting the important therapeutic contribution of natural products (Harvey, 2000). Marine natural products or derivatives thereof are included in this context because they are currently in different phases of clinical trials (Molinski et al., 2009; Mayer et al., 2010). On the other hand, antifouling chemical defenses have long been acknowledged as a protection mechanism for marine organism (e.g. Davis et al., 1989; Steinberg et al., 2001). Today, however, antifouling marine secondary metabolites have been recognized as a promising alternative to commercial paints (e.g., Rittschof, 2000; Bhadury \& Wright, 2004; Fusetani, 2011).

In the search for novel bioactive compounds for development of pharmaceutical drugs, many marine species have been collected in countries/ regions worldwide such as North America (Harbor Branch Media Lab Project, 2008), Canada (CBIN, 2005), Scandinavia (Aldridge, 2006), Australia (AIMS, 2002), New Zealand (The Treaty of Waitangi, 2006), Fiji (Aalbersberg, 1997), and Brazil (Veiga-Santos et al., 2010). In this bioprospecting context, the search for antifouling compounds included several marine species from different countries/regions such as the Antarctic (Amsler et al., 2000), the Mediterranean (Faimali et al., 2003), the Caribbean (Kelly et al., 2003), the Red Sea (Kelman et al., 1998), Australia (Butler et al., 1996), China (Dobretsov et al., 2005), France (Hellio et al., 2000), Singapore (Koh et al., 2002), Palauan (Sera et al., 1999), Japan (Takada et al., 2001) and Brazil (Da 


\section{Gama et al., 2008).}

Although seaweed exploitation accounts for a billionaire market of over U\$ 6 billion dollars/year (FAO, 2003; Smit, 2004), the development of seaweed secondary metabolites as therapeutic or antifouling agents is still in its embryonic stage. With a total annual use estimated at 8 million tons, seaweeds are the most abundant source of polysaccharides, including alginates, agar and carrageenans (Gomez D'Ayala et al., 2008; Laurienzo, 2010). The common uses are related to the food and cosmetic industries; however, biotechnological applications are rapidly expanding and hydrogels, for example, correspond to $10 \%$ of this market (Gomez D'Ayala et al., 2008; Laurienzo, 2010).

Screening for seaweed compounds with antifouling properties can provide effective, environmentally friendly alternatives to currently used antifouling paint booster biocides (Da Gama et al., 2002; Chambers et al., 2006; Fusetani, 2011), but few studies have explored this potential (Hellio \& Yebra, 2009). In fact, the core limitations in the development of new products from marine sources, including seaweeds, has changed throughout the years from the poor resolution of the chemical techniques used in the isolation and structural elucidation to the sustainability of the entire process (Hunt \& Vincent, 2006; Bugni et al., 2008a, b; Molinski, 2010).

As one of the world's largest countries, Brazil possesses about $8000 \mathrm{~km}$ of coastline and a rich macroalgae flora that is potentially a producer of bioactive secondary metabolites with pharmaceutical (Veiga-Santos et al., 2010) or antifouling (Da Gama et al., 2008) properties. In addition, this biodiversity offers unexplored opportunities and challenges for the discovery of new genes, enzymes, and processes, which might be very useful in the bioprospecting context. This review provides a current view on the bioprospecting of bioactives from seaweeds, highlighting the main metabolites, the potential of the different compounds produced by these marine organisms, the obstacles to development and promising alternatives to obtain bioactive compounds on a large scale.<smiles>CC(C)=CCC/C(C)=C/C1C[C@]1(C1CC1)[C@H]1CC=C(C=O)[C@H]1C=O</smiles>

1<smiles>Oc1cc(Cc2c(O)cc(O)c(Br)c2O)c(Br)c(Br)c1O</smiles>

4

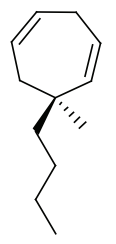

7<smiles>CC(=O)C1=Cc2c([nH]c3ccccc23)C(C(C)=O)=Cc2c1[nH]c1ccccc21</smiles><smiles>C=C1C[C@H](O)[C@H](Br)C(C)(C)[C@]12CCC(C)=C(C)C2</smiles>

5

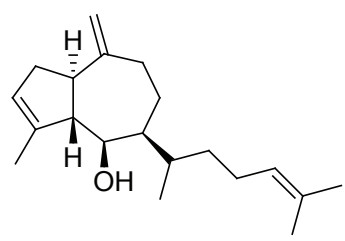

8<smiles>Cc1cc(O)cc2c1O[C@]1(C)CC[C@@H]3[C@@H](CC[C@@H]4C(C)(C)[C@@H](O)CC[C@@]43C)[C@H]1C2</smiles>

10<smiles>OCc1cc(O)c(O)c(Br)c1Br</smiles>

3<smiles>C#CCCCCC1O[C@H](CC)[C@@H](Br)CC=CC1OC(C)=O</smiles>

6<smiles>Oc1cc(O)c(Oc2cc(O)c(Oc3cc(O)c(-c4c(O)cc(O)cc4O)c(O)c3)c(O)c2)c(O)c1</smiles> 


\section{Seaweed chemicals}

Several species of seaweed have the capacity to produce a diverse array of secondary metabolites, which exhibit important and vital ecological roles as defense and/or signal compounds (Amsler, 2008) and are also of biotechnological interest (Smit, 2004; Hellio \& Yebra, 2009; Mayer et al., 2010). Examples of secondary metabolites produced by green seaweeds are halimedatrial (1) and caulerpenin (2); red seaweeds, lanosol (4), vidalol (5) and elatol (6); and brown seaweeds, dictyopterene C (7), pachydictyol A (8), fucodiphlorethol (9) and epitaondiol (10).

A quantitative analysis of the natural products of marine organisms demonstrated that more than 20000 compounds have been isolated and that the vast majority correspond to terpenoids and alkaloids from marine invertebrates (Hu et al., 2011; Blunt et al., 2011). Considering marine macroalgae, the number of isolated compounds corresponds to $10 \%$ of the total, mainly obtained from red and brown species. Halogenated compounds have received remarkable attention, mainly due to their strong bioactivity (Hu et al., 2011).

Brown seaweeds produce terpenoids, acetogenins, and terpenoid-aromatic compounds of mixed biosynthetic origin as their most common secondary metabolites (Blunt et al., 2011). In addition, these macroalgae also produce polyphenols (= phlorotannins), but in higher concentrations mainly in species from temperate (Toth \& Pavia, 2006) and polar regions (Fairhead et al., 2006). Red species encompass more than 1.500 different compounds, belonging to all major classes of secondary metabolites (Maschek \& Baker, 2008; Blunt et al., 2011). Among these chemicals, isoprenoid and acetogenin derivatives are recognized as the primary class of defensive metabolites in these algae (Harper et al., 2001). These red algae are also characterized by the production of an impressive array of halogenated compounds (Blunt et al., 2011). Green seaweeds, mainly the species of Bryopsidales are abundant and widely distributed in tropical seas and are known to produce sesquiterpenoid and diterpenoid compounds (Blunt et al., 2011).

Seaweeds are also a rich source of bioactive polysaccharides. As mentioned before, the main products of the seaweed industry are alginates, agar and carrageenans, which have the ability to increase the viscosity of aqueous solutions, to form gels of varying degrees of firmness, to form water-soluble films and to stabilize properties of water-based products (Draget et al., 2005). Throughout the years, these properties have also been explored by the biotechnology industry; tissue engineering and drug delivery are among the most promising applications for these polymers (Laurienzo, 2010). Additionally, sulfated polysaccharides from algae have been associated with anticancer and antiviral activities (Smit, 2004; Pomin \& Mourão, 2008; Vo \& Kim, 2010; Jiao et al., 2011), increasing the possibilities of biomedical applications (Gomez D'Ayala et al., 2008; Laurienzo, 2010). These sulfated polysaccharides are structurally diverse and heterogeneous, which make their chemical characterization a real challenge. As an example, at least fifteen different carrageenan structures have been described (Lahaye, 2001; Jiao et al., 2011).

\section{Potential of seaweeds-pharmaceuticals and antifouling agents}

Prior to the 1950s, the pharmacological properties of chemicals from seaweeds were restricted to traditional and folk medicine (Lincoln et al., 1991). However, during the 1980s and 90s, secondary metabolites possessing biological or promising pharmacological activities were evidenced in several species of seaweeds (see Smit, 2004, for a review). Due to these important evidences, these algae were the source of about $35 \%$ of the newly discovered chemicals in the period 1977-1987, followed by marine invertebrates (Ireland et al., 1993). In recent years, marine invertebrates and microorganisms have been the most prolific source of secondary metabolites and have become the focus of great interest since they provide a large proportion of bioactive compounds exhibiting broad biological activities (Blunt et al., 2009). According to Imhoff et al. (2011), modern marine biotechnology has shifted its focus to marine microbes, using large-scale fermentation techniques to incorporate sustainability into the development of new pharmaceuticals. Moreover, a whole new realm of possibilities awaits, considering the barely known microbial biodiversity and the important role of secondary metabolites in mediating interactions between microorganisms and between microorganisms and their hosts (Hill \& Fenical, 2010; Thomas et al., 2010; Waters et al., 2010).

There are several examples of pure compounds and crude extracts of seaweeds that exhibit biological activities. Here, we show examples of some of these activities, such as cytotoxicity, antiviral, antioxidant, antibacterial, neuromodulator, NAPDPH-dependent lipid peroxidation, antifungal, anthelmintic, antiinflammatory, and anticancer activities (Table 1). Among the substances isolated from seaweeds that have received most attention from pharmaceutical companies for development of new drugs are the sulfated polysaccharides (anticoagulants, anticancer and antivirals) and the kahalalide $\mathrm{F}$ (anticancer and anti-aids compounds) (Smit, 2004; Vo \& Kim, 2010; Jiao et al., 2011). 
Table 1. Examples of bioactivity exhibited by chemicals produced by seaweeds.

\begin{tabular}{|c|c|c|c|}
\hline Seaweed & Chemical & Activity & Reference \\
\hline Stypopodium sp. & stypoldione & cytotoxicity & Gerwick \& Fenical, 1981 \\
\hline Chondria sp. & condriamide A & cytotoxicity & Palermo et al., 1992 \\
\hline Chondria sp. & condriamide A & against HSV type II & Palermo et al., 1992 \\
\hline Eisenia bicyclis & polyphenols & antioxidant & Shibata et al., 2002; Heo et al., 2005 \\
\hline Gracilaria edulis & crude extract & antibacterial & Vallinayagam et al., 2009 \\
\hline Martensia fragilis & alkaloids & antioxidant & Takamatsu et al., 2003 \\
\hline Martensia fragilis & alkaloids & NAPDPH-depending lipid peroxidation & Takahashi et al., 1997 \\
\hline Rhodophyllis membranacea & polyhalogenated indoles & antifungal & Brennan \& Erickson, 1978 \\
\hline Bryopsis sp & kahalalide F & anticancer & Nuijen et al., 2000, Sparidans et al., 2001 \\
\hline Chondria atropurpurea & chondriamide B & anthelmintic & Davyt et al., 1998 \\
\hline Fucus vesiculosus & fucoidan & anticoagulant & Bernardi \& Springer, 1962 \\
\hline Botryocladia occidentalis & sulfated galactan & anticoagulant & Farias et al., 2000 \\
\hline Sargassum vulgare & alginate & anticancer & Sousa et al., 2007 \\
\hline Kappaphycus striatum & kappa-carrageenan & anticancer & Yuan et al., 2006 \\
\hline Cladosiphon okamuranus & fucan & antiviral & Hidari et al., 2008 \\
\hline Schizymenia dubyi & sulfated glucuronogalactan & antiviral & Bourgougnon et al., 1996 \\
\hline Undaria pinnatifida & crude extract & anti-inflamatory & Khan et al., 2008 \\
\hline
\end{tabular}

Marine secondary metabolites are viewed as sources of antifouling technology due to their ability to inhibit attachment, settlement, or growth of several marine organisms (Hellio et al., 2001). For seaweeds, the antifouling potential of its chemicals is due to antibacterial or antifungal activity, to broad inhibition of the settlement of marine organisms, verified in field experiments, or to specific actions against the settlement of benthic organisms, such as the mussel Perna perna, the polychaete Hydroides elegans, the bryozoan Bugula neritina, and the crustacean Balanus amphitrite (Table 2). Due to these evidences, seaweed secondary metabolites and polysaccharides are viewed as the most environmentally friendly antifouling strategy, based on the characterization and development of chemicals used by marine organisms to maintain their body surfaces free of encrusting organisms (Fusetani, 2004; Hellio \& Yebra, 2009; Qian et al., 2010).

The lists of chemicals exhibiting pharmaceutical (Table 1) and antifouling (Table 2) properties are no means exhaustive, but reveal that seaweed secondary metabolites possess noteworthy biological activities, with potential for application outside marine ecosystems as antifouling technology and in clinical use. Due to these few examples of broad biological activities, there is an interest among scientists and companies in the research and development of new bioactive agents from seaweeds. However, it is important to emphasize that drug or antifouling compound development is complicated, lengthy, and expensive.

\section{Drug and antifouling discoveries}

Both drug and antifouling discovery and development based on marine secondary metabolites require a very similar multidisciplinary approach. For example, both processes involve bioprospecting as the initial step, encompassing collection of samples of marine organisms. Of course, the key function of this first step is to provide some of the thousands of compounds that have interesting molecular structures and bioactivity (Kursar et al., 2007). In the next step, extracts from these organisms are prepared and subsequently tested for activities against various target diseases or micro- and/or macroorganism components of the fouling communities.

Usually, only a small number of extracts (hits) are registered for bioactivity. To develop a hit into a lead, a possible candidate for drug or antifouling, the hit extract needs to be purified to find the bioactive principle and to known its chemical or molecular structure. For example, 50000-100000 active compounds are necessary to generate a single lead (Hunt \& Vincent, 2006). The lead compound will be subjected to a series of additional trials that represent a need for supply of sample material. For example, in the preclinical phase of drug discovery, at first efficacy and toxicity tests of the lead are established in vivo in animals, before tests proceed with humans. On the other hand, for antifoulants tests in the field would be necessary to evaluate the efficacy against several benthic organisms in the natural environment, incorporation in paints and toxicity tests. In the drug context, only one in about fifty preclinical leads will result in a marketable drug (Hunt \& Vincent, 2006).

For drug discovery, approximately 15 years 
Table 2. Examples of antifouling activities exhibited by chemicals produced by seaweeds.

\begin{tabular}{|c|c|c|c|}
\hline Seaweed & Chemical & Activity & Reference \\
\hline Lobophora variegata & lobophorolide & antifungal & Kubanek et al., 2003 \\
\hline Canistrocarpus cervicornis & diterpenes & against Perna perna settlemtent & Bianco et al., 2009 \\
\hline Dictyota pfaffii & diterpene & broad antifouling effect in the field & Barbosa et al., 2007 \\
\hline Sargassum tenerrimum & polyphenols & against Hydroides elegans settlement & Lau \& Qian, 1997 \\
\hline Plocamium brasiliense & monoterpenes & against Balanus amphitrite settlement & Konig et al., 1999 \\
\hline Laurencia obtusa & crude extract & broad antifouling effect in the field & Da Gama et al., 2002 \\
\hline Delisea pulchra & furanones & against epibiosis & Dworjanyn et al., 1999 \\
\hline Laurencia majuscula & terpenoid & anti-bacteria & Vairappan et al., 2001 \\
\hline Laurencia rigida & elatol & against Bugula neritina settlement & Konig \& Wright, 1997 \\
\hline Bifuraria bifurcata & diterpenes & broad antifouling effect & Hellio et al., 2001 \\
\hline Ulva reticulata & polysaccharides & against Hydroides elegans settlement & Harder et al., 2004 \\
\hline
\end{tabular}

would be necessary, encompassing about thirteen years for research and clinical phases and two years for the administrative phase (Hunt \& Vincent, 2006). In addition, the development of a new drug is expensive, costing US\$ 900 million (Hunt \& Vincent, 2006). This estimative is not known for antifouling development, but it is possible to presume that there are similar aspects, both in terms of time and economic costs.

\section{Supply problem and alternatives}

Efforts at the discovery of drugs from the sea during the last forty years have yielded very few marine-derived compounds for the treatment of human diseases (Hill \& Fenical, 2010), encompassing only vidarabine (Ara-A), cytarabine (Ara-C), both used clinically since 1970s, and, most recently, ziconitide $\left(\right.$ Prialt $^{\circledR}$ ), trabectedin (Yondelis ${ }^{\circledR}$ ) and the halichondrin B synthetic derivative eribulin mesylate (Halaven ${ }^{\mathrm{TM}}$ ). Of course, only five drugs is disappointing given the high expectations for acquisition of drugs from the sea. The fact that very few marine natural products can be found on the shelves of pharmacies certainly is not due to a limited biological activity or low chemical diversity produced by marine organisms. For example, as stated above, seaweeds produce several secondary metabolites, many of them active as promising pharmaceuticals. In fact, the supply of material is a serious obstacle to the development of most marine secondary metabolites that are currently undergoing evaluation and trials (Munro et al., 1999; Waters et al., 2010). Since 1995, there has been a decrease in the interest in the search for new secondary metabolites from marine organisms, probably due to problems of supply.

The search for antifouling is only in the beginning when compared to pharmaceuticals, but it is possible to expect that supply is or will be the limitation for the development of an antifouling technology using marine secondary metabolites.

In general, the supply problem has limited the investigation of bioactive marine secondary metabolites and providing a sufficient amount of these chemicals may be a difficult task (Sukarmi \& Sabdono, 2008). Besides the small amount of compound found in the producing organism, or the limited quantity of the organism itself, the concentration of these chemicals can vary according to biotic and/or abiotic conditions (Sudatti et al., 2011). For example, in seaweeds, these compounds occur in relatively low concentrations, ranging from $0.2 \%$ to $2 \%$ of the algal dry mass, although compounds such as the polyphenols in brown seaweeds can occur at concentrations as high as $15 \%$ of the algal dry mass (Hay \& Fenical, 1988; Steinberg, 1992), also including compounds possessing high bioactivity.

Concerning polysaccharides, the problem of supply is attenuated since most of these molecules present a considerable yield compared to secondary metabolites. Carrageenan, for example, can account for $13-40 \%$ of the seaweed dry weight (Reani et al., 1998; Ramalingam et al., 2003). However, the standardization of a commercial product based on algal polysaccharides is still a challenge due to their structural diversity and heterogeneity, as well as to the great variability among different species, or even in the same species collected at different sites or in different seasons (Jiao et al., 2011).

The problem of supply is better known for marine invertebrates. For example, many pharmacologically interesting secondary metabolite candidates for clinical trials, such as ecteinascidin 743 isolated from the ascidian Ecteinascidia trubinata, bryostatins from the bryozoan Bugula neritina, or the halichondrins from the sponge Lissodendoryx, can be isolated only in minute yields. To use halochondrins for the treatment of cancer, it has been estimated that the annual need of $1-5 \mathrm{~kg}$ per year would require that 
about 3000-16000 metric tons of sponge biomass be collected and processed annually (Proksch et al., 2003). According to these perspectives, destruction of the environment and/or local extinction of species would or will be inevitable consequences.

Due to difficulty of gaining access to large tracts of biodiversity in natural environments, several alternatives or techniques have been developed to obtain secondary metabolites in non-natural ways. Besides offering an environmentally compatible and secure supply of naturally occurring metabolites for drugs or antifouling development, such technologies can be also used to produce more diverse chemicals. At first, both synthesis and culturing of marine organisms could reduce demand on wild sources and help to solve the problems of supply and impact on these natural resources. However, other alternatives or new experimental approaches, such as genetic recombinant techniques, chemoenzymatic synthesis, and in vitro tissue/cell culture have been mentioned as a possible solution to future supply problems (Cragg \& Newman, 2001; Pomponi, 1999; Hunt \& Vincent, 2006).

Synthetic production and/or manipulation are the most common alternative sources of bioactive compounds, including most of the marine drugs in clinical development today. Some compounds can be completely synthesized, whereas others may have their structure modified to increase their potency and/ or reduce toxicity. For example, semisynthetic routes have been developed to obtain ET-743, based on the precursor safracin B from the bacteria Pseudomonas flourescens (Cuevas et al., 2000), halichondrin B (Hart et al., 2000), and kalahide F (Lopez-Macia et al., 2001) to supply these anti-cancer compounds found in the ascidia Ecteinascidia turbinata (Rinehart et al., 1990), the sponge Lissodendoryx sp (Hart et al., 2000), and the green seaweed Bryopsis sp. (Newman \& Cragg, 2004), respectively.

Synthesis can be also employed to supply bioactive chemicals from seaweeds, but this approach needs to be considered in the context of economic viability. For example, the synthesis of the known antifouling compound elatol, found in low amounts in species of the red seaweed Laurencia (e.g., Sudatti et al., 2006) was obtained after several steps (White et al., 2008). Other examples could be listed, but most of the synthesis of bioactive marine secondary metabolites ivolve several steps and are not worried about economic or commercial viability.

With advances in combinatorial chemistry techniques, marine natural products can become platforms for further drug development (Ganesan, 2001). From a basic structure (scaffold) or pharmacophoric unit of the natural product, it is possible to build a diverse compound library around it, with the hope of discovering more active (and less toxic) analogs and derivatives (Cragg \& Newman, 2001; Ganesan, 2001; Rouhi, 2003). Thus, for example, an analog of ET-743, called phthalascidin (PT650), that is more potent, structurally simpler, easier to synthesize, and more stable was produced in this way (Cuevas et al., 2000). The basic structure of the natural product psammaplin A found in the marine sponge Psammaplysilla sp. was used to create a library of 3828 different compounds, six of which displayed antibacterial activity (Newman \& Cragg, 2004). Synthesis of furanones, analogs to the molecules found in the red seaweed Delisea pulchra (e.g., De Nys et al., 1993), was employed to develop a library of compounds exhibiting antifouling (see De Nys et al., 2006, for a review) and pharmacological (Lattmann et al., 1999) properties. These and other libraries can improve synthetic routes to the original natural product (Ganesan, 2001) and/or structural variants of the synthetic version not previously possible (Rouhi, 2003).

Aquaculture trials have been carried out to supply bioactive compounds from marine invertebrates such as the bryozoan Bugula neritina, the ascidian E. turbinata and the sponges Lissodendoryx sp., and Acanthella cavernosa. Most of these have succeeded in producing organisms with economically viable concentrations of bioactive compounds (Hart et al., 2000; Mendola, 2000, 2003). For seaweeds, efforts were undertaken mainly to develop cultures of species that produce colloids, such as alginates, carrageen, and agar (Lüning \& Pang, 2003), but very little is known about cultivation of seaweeds that produce secondary metabolites (but see Sudatti et al., 2011). However, the production of secondary metabolites in plants is generally a plastic trait that can be influenced by a number of biotic and abiotic extrinsic factors (e.g. Pavia \& Brock, 2000), but this aspect is also very poorly explored for seaweeds (e.g. Sudatti et al., 2011).

Tissue cultures have been also used to obtain adequate quantities of commercially valuable chemicals, to produce compounds for screening (Stafford et al., 1998) or, by addition of chemicals, elicit the expression of different metabolic pathways (Gleba et al., 1999). However, these alternatives are better known for compounds from plants (see Bourgaud et al., 2001 for review). However, as known for seaweeds that are producers of colloids (see Hayashi et al., 2008), this technique could be a promising way to obtain bioactive secondary metabolites from seaweeds.

Another potential alternative for supply is to remove the appropriate genetic material that codes for bioactive secondary metabolites and incorporate it into a microorganism. For example, by introducing combinations of genes not found in nature into a productive strain of Streptomyces, a range of novel chemicals can be produced for screening (Katz \& McDaniel, 1999; McDaniel et al., 1995). Heterologous expression of genes encoding bioactive compounds 
may also be a promising alternative to the supply problem. For example, the development of bryostatins for biomedical and biotechnological applications included the cultivation of the bacterial symbiont and heterologous expression of the biosynthesis gene of this molecule (Trindade-Silva et al., 2010). Of course, these procedures could be useful for supplying bioactive compounds from seaweeds and other marine organisms.

Culturing of microorganisms (e.g., bacteria) may have a considerable potential for producing a sustainable supply of bioactive marine natural products (Thomas et al., 2010), because many of the compounds found in marine invertebrates organisms may be of microbial origin (Jensen \& Fenical, 2000). In fact, microbial symbionts are often suggested to be the real producers of the secondary metabolites found in marine invertebrates, usually based on the structural similarities to known microbial compounds (TrindadeSilva et al., 2010). For example, the structurally and biosynthetically complex bryostatins found in the bryozoan $B$. nertitina are typical bacterial secondary metabolites and are probably produced by the symbiotic bacterium 'Candidatus Endobugula sertula' (Lopanik et al., 2004; Davidson et al., 2001). To culture a spongeassociated symbiont remains very difficult because of the difficulty of isolating and maintaining a pure cultivation, but initial successes have been obtained ( $\mathrm{Li}$ et al., 2007; Muscholl-Silberhorn et al., 2007).

\section{Perspectives}

On the basis of available information, seaweeds constitute a potential resource of bioactive secondary metabolites for bioprospecting. However, also according to available information, it is possible to verify that bioprospecting for bioactive secondary metabolites from seaweeds is a very complex process, including sample collection, activity detection, identification of leads, and development of preclinical and clinical trials in the context of pharmaceuticals. This type of marine bioprospecting also includes and/ or is limited by the supply of molecules for both the clinical trials and commercial scale-up. However, today bioprospecting for these molecules is almost synonymous with screening, because most of the studies provide information on the biological activities of the compounds and, sometimes, on the mechanism of action for molecules that can be promising in the context of pharmaceuticals or antifouling. Despite the high potential of marine secondary metabolites as pharmaceuticals and antifouling agents, few sustainable production methods have been developed to supply these chemicals.

Given the concern related to the sustainability of drug discovery based on marine natural products, current research trends include the search for reliable sources of molecules in associated microorganisms, encompassing endophytic fungi, as well as the use of a multidisciplinary approach linking molecular biology to natural products discovery (Tharkur et al., 2008; Hill \& Fenical, 2010). While genome mining of gene clusters related to the biosynthesis of molecules increase the possibilities of finding new carbon skeletons, it also creates the knowledge to expedite the use of heterologous expression in natural and "unnatural" product biosynthesis (Lane \& Moore, 2011).

Recently, the Brazilian government has included marine biotechnology as a strategic research field for the development of the country, aiming at the sustainable exploitation of the so-called "Blue Amazon", which includes the total area of 3.5 million $\mathrm{km}^{2}$ of the Brazilian exclusive economic zone in the Atlantic Ocean with its unprecedented associated biodiversity. Brazilian bioprospecting is only in the beginning, but this is the crucial moment to think about better strategies. There are good reasons to believe that many species of Brazilian seaweeds have unique characteristics that can be exploited to create the basis for new products and processes, such as novel antifouling agents (e.g., Da Gama et al., 2008) and pharmaceuticals (VeigaSantos et al., 2010). However, as verified worldwide, supply is a serious obstacle today and a limiting factor for the development of pharmaceuticals using marine secondary metabolites. Indeed, supply problems have contributed to the disappointing fact that, after forty years, only few marine-derived compounds are in use for treatment of human diseases.

In general, Brazilian seaweeds are small and probably will fail to furnish large biomass for the sustainable development of antifouling compounds or pharmaceuticals. On the other hand, the risk of overexploration grows if a seaweed bioactive compound is structurally complex, highly potent, and/or its mechanism of action is a novelty. After detection of a promising lead by screening, it would then be necessary to solve the supply problem in order to reduce the impact on the natural populations and the development of antifouling and pharmaceutical technologies. In fact, contemporary bioprospecting has multiple goals, encompassing conservation of biodiversity, the sustainable management of natural resources and economic development (Beattie et al., 2010).

A bioprospecting program based on the sustainable use of marine biodiversity has attracted much attention and this emerging approach is especially important to be developed in Brazil, not only to reap economic benefits but also to promote the protection and conservation of marine biodiversity. In other words, how can secondary metabolite bioprospecting 
be implemented in such a way as to promote sustainable use and the protection and conservation of marine biodiversity, as well as contribute to economic development to Brazil?

\section{Acknowledgments}

The authors thank: Conselho Nacional de Desenvolvimento Científico e Tecnológico, Fundação de Amparo à Pesquisa do Estado do Rio de Janeiro, Financiadora de Estudos e Projetos and Coordenação de Aperfeiçoamento de Pessoal de Nível Superior, who have long been sponsors of our work on marine chemical ecology and bioactivity of marine natural products.

\section{References}

Aalbersberg B 1997. Biodiversity prospecting in the seas around Verata Tikina. http://www.worldwildlife.org/ bsp/bcn/learning/ar97/97_fiji20.htm. Accessed in march 2011.

AIMS 2002. Annual report 2000-2001. AIMS (Australian Institute of Marine Sciences). http://www.aims.gov. au/pages/about/ar20002001/ar20002001-00.html. Accessed March 2011.

Aldridge S 2006. Marine bioprospecting for novel drugs. http://www.genengnews.com/articles/chitem. aspx?aid=1958\&chid=4. Accessed March 2011.

Amsler CD 2008. Algal chemical ecology. Berlin: SpringerVerlag.

Amsler CD, Moelber CB, McClintock JB, Iken KB, Baker BJ 2000. Chemical defenses against diatom fouling in Antarctic marine sponges. Biofouling 16: 29-45.

Barbosa JP, Fleury BG, Teixeira VL, Da Gama BAP, Pereira RC 2007. Natural products as antifoulants in a brazilian brown alga Dictyota pfaffii (Phaeophyta, Dictyotales). Biochem Syst Ecol 35: 549-553.

Beattie AJ, Hay M, Magnusson B, De Nys R, Meathers J, Vincent JFV 2010. Ecology and bioprospecting. Austral Ecol 36: 341-356.

Bernardi G, Springer GF 1962. Properties of highly purified fucan. J Biol Chem 237: 75-80.

Bhadury P, Wright PC 2004. Exploitation of marine algae: biogenic compounds for potential antifouling applications. Planta 219: 561-578.

Bianco EM, Rogers R, Teixeira VL, Pereira RC 2009. Antifoulant diterpenes produced by the brown seaweed Canistrocarpus cervicornis. J Appl Phycol 21: 341-346.

Blunt JW, Copp BR, Hu WP, Munro MHG, Northcote PT, Prinsep MR 2009. Marine natural products. Nat Prod Rep 26: 170-244.

Blunt JW, Copp BR, Munro MHG, Northcote PT, Prinsep MR 2011. Marine natural products. Nat Prod Rep 28: 196-
268.

Bourgaud F, Gravot A, Milesi S, Gontier E 2001. Production of plant secondary metabolites: a historical perspective. Plant Sci 161: 839-851.

Bourgougnon N, Lahaye M, Quemener B, Chermann JC, Rimbert M, Cormaci M, Furnari G, Komprobst JM 1996. Annual variation in composition and in vitro anti-HIV-1 activity of the sulfated glucuronogalactan from Schizymenia dubyi (Rhodophyta, Gigartinales). J Appl Phycol 8: 155-161.

Brennan MR, Erickson KL 1978. Polyhalogenated indoles from the marine alga Rhodophyllis membranacea Harvey. Tetrahedron Lett 19: 1637-1640.

Bugni TS, Richards B, Bhoite L, Cimbora D, Harper MK, Ireland CM 2008a. Marine natural product libraries for high-throughput screening and rapid drug discovery. J Nat Prod 71: 1095-1098.

Bugni TS, Harper MK, McCulloch MWB, Reppart J, Ireland CM 2008b. Fractionated marine invertebrates extract libraries for drug discovery. Molecules 13: 13721383.

Butler AJ, Van Altena IA, Dunne SJ 1996. Antifouling activity of lyso-platelet-activating factor extracted from australian sponge Crella incrustans. J Chem Ecol 22: 2041-2061.

CBIN 2005. Marine and coastal biodiversity. CBIN (Canadian Biodiversity Information Network). http://www. cbin.ec.gc.ca/enjeux-issues/marine.cfm?lang=eng. Accessed in november 2011.

Chambers LD, Stokes KR, Walsh FC, Wood RJ K 2006. Modern approaches to marine antifouling coatings. Surf Coat Technol 201: 3642-3652.

Cragg GM, Newman DJ 2001. Natural product drug discovery in the next millennium. Pharm Biol 39: 8-17.

Cuevas C, Perez M, Martin MJ, Chicharro JL, FernandezRivas C, Flores M, Francesch A, Gallego P, Zarzuelo M, de la Calle F, Garcia J, Polanco C, Rodriguez I, Manzanares I 2000. Synthesis of ecteinascidian ET743 and phthalascidin Pt-650 from cyanosafracin B. Org Lett 2: 2545-2548.

Da Gama BAP, Carvalho AGV, Weidner K, Soares AR, Coutinho R, Fleury BG, Teixeira VL, Pereira RC 2008. Antifouling activity of natural products from brazilian seaweeds. Bot Mar 51: 191-201.

Da Gama BAP, Pereira RC, Carvalho MGV, Coutinho R, Yoneshigue-Valentin Y 2002. The effects of seaweed secondary metabolites on biofouling. Biofouling 18: 13-20.

Davidson SK, Allen SW, Lim GE, Anderson CM, Haygood MG 2001. Evidence for the biosynthesis of bryostatins by the bacterial symbiont "Candidatus Endobugula sertula" of the bryozoan Bugula neritina. Appl Environ Microb 67: 4531-4537.

Davis AR, Targett NM, McConnel OJ, Young CM 1989. Epibiosis of marine algae and benthic invertebrates: 
natural products chemistry and other mechanisms inhibiting settlement and overgrowth. Bioorg Mar Chem 3: 85-114.

Davyt D, Entz W, Fernandez R, Mariezcurrena R, Mombru AW, Saldana J, Dominguez L, Coll J, Manta E 1998. A new indole derivative from the red alga Chondria atropurpurea. Isolation, structure determination, and anthelmintic activity. $J$ Nat Prod 61: 1560-1563.

De Nys R, Givskov M, Kumar N, Kjelleberg S, Steinberg PD 2006. Furanones. In: Fusetani N, Clare AS (org.). Antifouling compounds. Progress in Molecular and Subcellular Biology. Heidelberg: Springer, p. 55-86.

De Nys R, Wright AD, Konig GM, Sticher O 1993. New halogenated furanones from the marine alga Delisea pulchra (cf. fimbriata). Tetrahedron 49: 1121311220.

Demunshi Y, Chugh A 2010. Role of traditional knowledge in marine bioprospecting. Biodivers Conserv 19: 3015 3033.

Dobretsov SV, Dahms HU, Qian PY 2005. Antibacterial and anti-diatom activity of Hong Kong sponges. Aquat Microb Ecol 38: 191-201.

Draget KI, Smidsrod O, Skjak-Braek G 2005. Alginates from algae. In: Steinbüchel A, Rhee SK (org). Polysaccharides and polyamides in food industry. properties, production, and patents. Weinheim: Willey-VCH Verlag GmbH \& Co. p. 1-30.

Dworjanyn SA, De Nys R, Steinberg PD 1999. Localization and surface quantification of secondary metabolites in the red alga Delisea pulchra. Mar Biol 133: 727-736.

Faimali M, Sepcic K, Turk T, Geraci S 2003. Non-toxic antifouling activity of polymeric 3-alkylpyridinium salts from the Mediterranean sponge Reniera sarai Pulitzer-Finali. Biofouling 19: 47-56.

Fairhead VA, Amsler CD, McClintock JB, Baker BJ 2006. Lack of defense or phlorotannins induction by UV radiation or mesograzers in Desmarestia anceps and D. menziesii (Phaeophyceae). J Phycol 42: 11741183.

FAO 2003. Inland water resources and aquaculture service. Review of the state of world aquaculture. FAO Fisheries Circular. Rome: FAO.

Farias WRL, Valente AP, Pereira MS, Mourão PAS 2000. Structure and anticoagulant activity of sulfated galactans. Isolation of a unique sulfated galactan from the red algae Botryocladia occidentalis and comparison of its anticoagulant action with that of sulfated galactans from invertebrates. $\mathrm{J} \mathrm{Biol} \mathrm{Chem}$ 275: 29299-29307.

Farnsworth NR 1994. Ethnobotany and the search for new drugs. Chichester: Wiley.

Fusetani N 2004. Biofouling and antifouling. Nat Prod Rep 21: $94-104$.

Fusetani N 2011. Antifouling marine natural products. Nat Prod Rep 28: 400-410.
Ganesan A 2001. Integrating natural product synthesis and combinatorial chemistry. Pure Appl Chem 73: 10331039.

Gerwick WH, Fenical W 1981. Ichthyotoxic and cytotoxic metabolites of the tropical brown alga, Stypopodium zonale. J Org Chem 46: 22-27.

Gleba D, Borisjuk NV, Borisjuk LG, Kneer R, Poulev A, Sarzhinskaya M, Dushenkov S, Logendra S, Gleba YY, Raskin I 1999. Use of plant roots for phytoremediation and molecular farming. P Natl Acad Sci USA 96: 59735977.

Gomez d'Ayala G, Malinconico M, Laurienzo P 2008. Marine derived polysaccharides for biomedical applications: chemical modification approaches. Molecules 13: 20692106.

Harbor Branch Media Lab Project 2008. "Drugs from the sea" index. http://www.marinebiotech.org/dfsindex_ alpha.html. Accessed in march 2011.

Harder T, Dobretsov S, Qian PY 2004. Waterborne polar macromolecules act as algal antifoulants in the seaweed Ulva reticulata. Mar Ecol-Prog Ser 274: 133-141.

Harper MK, Bugni TS, Copp BR, James RD, Lindsay BS, Richardson AD, Schnabel PC, Tasdemir D, VanWagoner RM, Verbitski SM, Ireland CM 2001. Introduction to the chemical ecology of marine natural products. In: McClintock JB, Baker BJ (org.). Marine chemical ecology. 1. ed. Boca Raton: CRC Press, p. 3-79.

Hart JB, Lill RE, Hickford SJH, Blunt JW, Munro MHG 2000. The halichondrins: chemistry, biology, supply and delivery. In: Fusetani N (org.). Drugs from the sea. Basel: Karger, p. 134-154.

Harvey A 2000. Strategies for discovering drugs from previously unexplored natural products. Drug Discov Today 5: 294-300.

Hay ME, Fenical W 1988. Marine plant-herbivore interactions: the ecology of chemical defense. Annu Rev Ecol Syst 19: 111-145.

Hayashi L, Yokoya NS, Kikuchi DM, Oliveira EC 2008. Callus induction and micropropagation improved by colchicine and phytoregulators in Kappaphycus alvarezii (Rhodophyta, Solieriaceae). J Appl Phycol 20: 653-659.

Hellio C, Bremer G, Pons Am, Le Gal Y, Bourgougnon N 2000. Inhibition of the development of microorganisms (bacteria and fungi) by extracts of marine algae from Britanny, France. Appl Microbiol Biot 54: 543-549.

Hellio C, Thomas-Guyon H, Culioli G, Piovetti L, Bourgougnon N, Le Gal Y 2001. Marine antifoulants from Bifurcaria bifurcata (Phaephyceae, Cystoseiraceae) and other brown macroalgae. Biofouling 17: 189-201.

Hellio C, Yebra D 2009. Advances in marine antifouling coatings and technologies. Cambridge: Woodhead Publishing Limited.

Heo SJ, Park PJ, Park EJ, Kim SK, Jeon YJ 2005. Antioxidant 
activity of enzymatic extracts from a brown seaweed Ecklonia cava by electron spin resonance spectrometry and comet assay. Eur Food Res Technol 221: 41-47.

Hidari KIPJ, Takahashi N, Arihara M, Nagaoka M, Morita K, Suzuki T 2008. Structure and anti-dengue virus activity of sulfated polysaccharide from a marine alga. Biochem Bioph Res Co 376: 91-95.

Hill RT, Fenical W 2010. Pharmaceuticals from marine natural products: surge or ebb? Curr Opin Biotech 21: 777-779.

Hu GP, Yuan J, Sun L, She ZG, Wu JH, Lan XJ, Zhu X, Lin YG, Chen SP 2011. Statistical research on marine natural products based on data obtained between 1985 and 2008. Mar Drugs 9: 514-525.

Hunt B, Vincent ACJ 2006. Scale and sustainability of marine bioprospecting for pharmaceuticals. Ambio 35: 5764.

Imhoff JF, Labes A, Wiese J 2011. Bio-mining the microbial treasures of the ocean: new natural products. Biotechnol Adv 29: 468-482.

Ireland CM, Copp BR, Foster MP, McDonald LA, Radisky DC, Swersey JC 1993. Biomedical potential of marine natural products. In: Attaway DH, Zaborsky OR (org.). Marine Biotechnology. New York: Plenum Press, p. 1-43.

Jensen PR, Fenical W 2000. Marine microorganisms and drug discovery: current status and future potential. In: Fusetani N (Ed). Drugs from the sea. Basel: Karger, p. 6-29.

Jiao G, Yu G, Zhang J, Ewart HE 2011. Chemical structures and bioactivities of sulfated polysaccharides from marine algae. Mar Drugs 9: 196-223.

Katz L, McDaniel R 1999. Novel macrolides through genetic engineering. Med Res Rev 19: 543-558.

Kelly SR, Jensen PR, Henkel TP, Fenical W, Pawlik JR 2003. Effects of Caribbean sponge extracts on bacterial attachment. Aquat Microb Ecol 31: 175-182.

Kelman D, Kushmaro A, Loya Y, Kashman Y, Benayashu Y 1998. Antimicrobial activity of a Red Sea soft coral, Parerythropodium fulvum fulvum: reproductive and developmental considerations. Mar Ecol-Prog Ser 169: 87-95.

Khan MNA, Suk-Choi J, Lee MC, Kim E, Nam TJ, Fujii H, Hong YK 2008. Anti-inflammatory activities of methanol extracts from various seaweed species. $J$ Environ Biol 29: 465-469.

Koh LL, Tan TK, Chou LM, Goh NKC 2002. Antifungal properties of Singapore gorgonians: a preliminary study. J Exp Mar Biol Ecol 273: 121-130.

Konig GM, Wright AD 1997. Laurencia rigida: chemical investigations of its antifouling dichloromethane extract. J Nat Prod 60: 967-970.

Konig GM, Wright AD, de Nys R 1999. Halogenated monoterpenes from Plocamium costatum and their biological activity. J Nat Prod 62: 383-385.
Kubanek J, Jensen PR, Keifer PA, Sullards C, Collins DO, Fenical W 2003. Seaweed resistance to microbial attack: A targeted chemical defense against marine fungi. P Natl Acad Sci USA 100: 6916-6921.

Kursar TA, Caballero-George CC, Capson TL, Cubilla-Rios L, Gerwick WH, Gupta MP, Ibaňes A, Linington RG, Mcphai KL, Ortegabarria E, Romero LI, Solis PN, Cole PD 2007. Securing economic benefits and promotion conservation through bioprospecting. Bioscience 56: 1005-1012.

Lahaye M 2001. Developments on gelling algal galactans, their structure and physico-chemistry. J Appl Phycol 13: 173-184.

Lane AL, Moore BS 2011. A sea of biosysnthesis: marine natural products meet the molecular age. Nat Prod Rep 28: 411-428.

Lattmann E, Billington DC, Langley CA 1999. Synthesis of combinatorial libraries of 3,4,5-trisubstituted 2(5H)furanones. Part One: Construction of a sub-library of halogenated 5-alkoxy-2(5H)-furanones. Drug Des Discovery 16: 237-42.

Lau SCK, Qian PY 1997. Phlorotannins and related compounds as larval settlement inhibitors of the tubebuilding polychaete Hydroides elegans. Mar EcolProg Ser 159: 219-227.

Laurienzo P 2010. Marine polysaccharides in pharmaceutical applications: an overview. Mar Drugs 8: 2435-2465.

Li Z, He L, Miao X 2007. Cultivable bacterial community from south China sea sponge as revealed by DGGE fingerprinting and 16S rDNA phylogenetic analysis. Curr Microbiol 55: 465-472.

Lincoln RA, Strupinski K, Walker JM 1991. Bioactive compounds from algae. Life Chem Rep 8: 97-183.

Lopanik N, Lindquist N, Targett N 2004. Potent cytotoxins produced by a microbial symbiont protect host larvae from predation. Oecologia 139: 131-139.

Lopez-Macia A, Jimenez JC, Royo M, Giralt E, Alberico F 2001. Synthesis and structure determination of Kahalalide F. J Am Chem Soc 123: 11398-11401.

Lüning K, Pang S 2003. Mass cultivation of seaweeds: current aspects and approaches J Appl Phycol 15: 115-119.

Maschek JA, Baker BJ 2008. The chemistry of algal secondary metabolism. In: Amsler CD (org.). Algal chemical ecology. Berlin: Springer-Verlag. p. 1-24.

Mayer AMS, Glaser KB, Cuevas C, Jacobs RS, Kem W, Little RD, McIntosh JM, Newman DJ, Potts BC, Shuster DE 2010. The odyssey of marine pharmaceuticals: a current pipeline perspective. Trends Pharmacol Sci 31: 255-265.

McDaniel R, Ebert-Khosla S, Hopwood DA, Khosla C 1995. Rational design of aromatic polyketide natural products by recombinant assembly of enzymatic subunits. Nature 375: 548-554.

Mendola D 2000. Aquacultural production of bryostatin 1 and Ecteinascidian 743. In: Fusetani N (org.). Drugs from the 
sea. Basel:Karger, p. 120-133.

Mendola D 2003. Aquaculture of three phyla of marine invertebrates to yield bioactive metabolites: process developments and economics. Biomol Eng 20: 441458.

Molinski TF 2010. Microscale methodology for structure elucidation of natural products. Curr Opin Biotech 21: 819-826.

Molinski TF, Dalisay, DS, Lievens SL, Saludes JP 2009. Drug development from marine natural products. Nat Rev Drug Discov 28: 69-85.

Munro MHG, Blunt JW, Dumdei EJ, Hickford SJH, Lill RE, Li S, Battershill CN, Duckworth AR 1999. The discovery and development of marine compounds with pharmaceutical potential. J Biotechnol 70: 1525.

Muscholl-Silberhorn A, Thiel V, Imhoff JF 2007. Abundance and bioactivity of cultured sponge-associated bacteria from the Mediterranean Sea. Microb Ecol 55: 94106.

Newman DJ, Cragg GM 2004. Marine natural products and related compounds in clinical and advanced preclinical trials. J Nat Prod 67: 1216-1238.

Nuijen B, Bouma M, Talsma H, Manada C, Jimeno JM, LopezLazaro L, Bult A, Beijnen JH 2000. Development of a lyophilized parenteral pharmaceutical formulation of the investigational polypeptide marine anticancer agent kahalalide F. Drug Dev Ind Pharm 27: 767780.

Palermo JA, Flower BP, Seldes AM 1992. Chondriamides $\mathrm{A}$ and $\mathrm{B}$ new indolic metabolities from red algae Chondria sp. Tetrahedron Lett 33: 3097-3100.

Pavia H, Brock E 2000. Extrinsic factors influencing phlorotannin production in the brown alga Ascophyllum nodosum. Mar Ecol-Prog Ser 193: 285-294.

Pomin VH, Mourão PA 2008. Structure, biology, evolution, and medical importance of sulfated fucans and galatans. Glycobiology 12: 1016-1027.

Pomponi SA 1999. The bioprocess-technological potential of the sea. J Biotechnol 70: 5-13.

Proksch P, Edrada-Ebel R, Ebel R 2003. Drugs from the seaopportunities and obstacles. Mar Drugs 1: 5-17.

Qian PY, Xu Y, Fusetani N 2010. Natural products as antifouling compounds: recent progress and future perspectives. Biofouling 26: 223-234.

Ramalingam JR, Kaliaperumal N, Kalimuthu, S. 2003. Commercial scale production of production of carrageenan from red algae. Seaweed Res Utiln 25: $37-46$.

Reani A, Cosson J, Parker A 1998. Seasonal variation of growth, carrageenan content and rheological properties of Eytoclonium purpureum (Huds.). Bot Mar 41: 383-387.

Rinehart K, Holt TG, Fregeau NL, Stroh JG, Kiefer PA, Sun F, Li L, Martin DG 1990. Ecteinascidins 729, 743,
745, 759A, 759B, and 770: potent antitumor agents from the Caribbean tunicate Ecteinascidia turbinata. J Org Chem 55: 4512-4515.

Rittschof D 2000. Natural product antifoulants: one perspective on the challenges related to coatings development. Biofouling 15: 119-127.

Rouhi AM 2003. Moving beyond natural products. Chem Eng News 81: 104-107.

Sera Y, Adachi K, Shizuri Y 1999. A new epidioxy sterol as an antifouling substance from a Palauan marine sponge, Lendenfeldia chondrodes. J Nat Prod 62: 152-154.

Shibata T, Fujimoto K, Nagayama K, Yamaguchi K, Nakamura T 2002. Inhibitory activity of brown algal phlorotannins against hyaluronidase. Int J Food Sci Tech 37: 703-709.

Smit AJ 2004. Medicinal and pharmaceutical uses of seaweed natural products: a review. J Appl Phycol 16: 245-262.

Sousa APA, Torres MR, Pessoa C, Moraes MO, Rocha-Filho FD, Alves APNN, Costa-Lotufo LV 2007. In vivo growth-inhibition of sarcoma 180 tumor by alginates from brown seaweed Sargassum vulgare. Carbohyd Polym 69: 7-13.

Sparidans RW, Stokvis E, Jimeno JM, Lopez-Lazaro L, Schellens JH, Beijnen JH 2001. Chemical and enzymatic stability of a cyclic depsipeptide, the novel, marine-derived, anticancer agent kahalalide F. Anti-Cancer Drug 12: 575582.

Stafford AM, Pazoles CJ, Siegel S, Yeh L-A 1998. Plant cell culture: a vehicle for drug discovery. In: Harvey AL (org.). Advances in drug techniques. New York: John Wiley \& Sons, p. 53-64.

Steinberg PD 1992. Geographical variation in the interaction between marine herbivores and brown algal secondary metabolites. In: Paul VJ (org.). Ecological roles of marine natural products. 1. ed. New York: Comstock Publishing Associates, p. 51-91.

Steinberg PD, de Nys R, Kjelleberg S 2001. Chemical mediation of surface colonization. In: McClintock JB, Baker BJ (org.). Marine chemical ecology. 1. ed. Boca Raton: CRC Press, p. 355-387.

Sudatti DB, Fujii MT, Rodrigues SV, Turra A, Pereira RC 2011. Effect of abiotic factors on growth and chemical defense content in Laurencia dendroidea J. Agardh (Ceramiales, Rhodophyta) cultivated clones. Mar Biol 158: 14391446.

Sudatti DB, Rodrigues SV, Pereira RC 2006. Quantitative GC-ECD analysis of halogenated metabolites: determination of elatol on surface and within-thallus of Laurencia obtusa. J Chem Ecol 32: 835-843.

Sukarmi S, Sabdono A 2008. Ethical perspectives of sustainable use of reef's invertebrates as a source of marine natural products. J Coastal Dev 11: 97-103.

Takada N, Watanabe R, Suenga K, Yamada K, Ueda K, Kita M, Uemura D 2001. Zamamistatin, a significant antibacterial bromotyrosine derivative, from 
the Okinawa sponge Pseudoceratina purpurea. Tatrahedron Lett 42: 5265-5267.

Takahashi S, Matsunaga T, Hasegawa C, Saito H, Fujita D, Kiuchi F, Tsuda Y 1997. Studies on bioactive substances in natural resources. Toyama-ken Yakuji Kenkyusho Nenpo 24: 53-57.

Takamatsu S, Hodges TW, Rajbhandari I, Gerwick WH, Hamann MT, Nagle DG 2003. Marine natural products as novel antioxidant prototypes. J Nat Prod 66: 605608.

Tharkur NL, Jain R, Natalio F, Hamer B, Thakur AN, Müller WEG 2008. Marine molecular biology: an emerging field of biological sciences. Biotechnol Adv 26: 233 245.

The Treaty of Waitangi 2006. What the treaty says. http:// www.immigration.govt.nz/migrant/settlementpack/ treaty/WhatTheTreatySays/. Accessed in march 2011.

Thomas TRA, Kavlekar DP, LokaBharathi PA 2010. Marine drugs from sponge-microbe association-a review. Mar Drugs 8: 1417-1468.

Tittensor DP, Mora C, Jetz W, Lotze HK, Ricard D, Berghe EV, Worm B 2010. Global patterns and predictors of marine biodiversity across taxa. Nature 466: 10981103 .

Toth GB, Pavia H 2006. Artificial wounding decreases plant biomass and shoot strength of the brown seaweed Ascophyllum nodosum (Fucales, Phaeophyceae). Mar Biol 148: 1193-1199.

Trindade-Silva AE, Lim-Fong GE, Sharp KH, Haygood MG 2010. Bryostatins: biological context and biotechnological prospects. Curr Opin Biotech 21: 834-842.

Vairappan CS, Suzuki M, Abe T, Masuda M 2001. Halogenated metabolites with antibacterial activity from the Okinawan
Laurencia species. Phytochemistry 58: 517-523.

Vallinayagam K, Arumugam R, Ragupathi RKR, Thirumaran G, Anantharaman P 2009. Antibacterial activity of some selected seaweeds from Pudumadam coastal regions. Global J Pharmacol 3: 50-52.

Veiga-Santos P, Pelizzaro-Rocha KJ, Santos AO, UedaNakamura T, Dias-Filho BP, Silva SO, Sudatti DB, Bianco EM, Pereira RC, Nakamura CV 2010. In vitro anti-trypanosomal activity of elatol isolated from red seaweed Laurencia dendroidea. Parasitology 137: 1661-1670.

Vo TS, Kim SK 2010. Potential Anti-HIV agents from marine resources: an overview. Mar Drugs 8: 2871-2892.

Waters AL, Hill RT, Place AR, Hamann MT 2010. The expanding role of marine microbes in pharmaceutical development. Curr Opin Biotech 21: 780-786.

White DE, Stewart IC, Grubbs RH, Stoltz BM 2008. The catalytic asymmetric total synthesis of elatol. $\mathrm{J} \mathrm{Am}$ Chem Soc 130: 810-811.

Yuan H, Song J, Li X, Li N, Dai J 2006. Immunomodulation and antitumor activity of $\kappa$-carrageenan oligosaccharides. Cancer Lett 243: 228-234.

\section{*Correspondence}

\section{Renato Crespo Pereira}

Departamento de Biologia Marinha, Instituto de Biologia, Universidade Federal Fluminense

Morro do Valonguinho, s/n, Caixa Postal 100.644, 24.001-

970 Centro, Niterói-RJ,

rcrespo@id.uff.br

Tel.: 552126295072

Fax: 552126292292 